\title{
Invasive Management of Abscess Due to Splenic Infarct: A Retrospective Analysis of Thirteen Cases
}

\author{
Splenik Enfarkta Bağlı Absenin Invaziv Tedavisi: On Üç Olgunun Retrospektif \\ Analizi
}

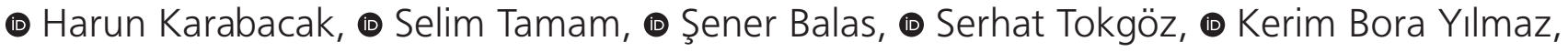 \\ (1) Melih Akıncı*, (1) Onur Ergün*, (1) Hasan Ali Durmaz*, (1) Metin Aydın, (1) Muzaffer Akkoca, \\ (1) Cem Azılı
}

University of Health Sciences, Dışkapı Yıldırım Beyazıt Training and Research Hospital, Clinic of General Surgery, Ankara, Turkey

*University of Health Sciences, Dışkapı Yıldırım Beyazıt Training and Research Hospital, Clinic of Radiology, Ankara, Turkey

\section{Abstract}

\begin{abstract}
Aim: Splenic infarction is a rare condition successfully treated with medical methods in general. The aim of this study was to evaluate the invasive treatment options in patients with splenic infarction-associated abscess
\end{abstract}

Methods: Files of thirteen patients, who underwent percutaneous drainage or a surgical procedure due to abscess as a result of splenic infarction, were retrospectively reviewed. Age symptoms, results of physical and radiological examinations and therapeutic methods were analyzed.

Results: A total of 13 patients with the mean age of $56 \pm 18$ years were included in the study. Seven (54\%) patients were female and six (46\%) were male. Acute abdomen was observed in 11 patients (85\%), and acute abdomen as well as high white blood cell (WBC) count (>15000/mL) in nine patients $(70 \%)$. Percutaneous drainage was performed in five patients (39\%) and splenectomy in eight patients (62\%), all of whom were diagnosed with splenic abscess by means of computed tomography. There was no difference in age, gender, acute abdomen, WBC count, platelet count and mortality between patients who underwent splenectomy and percutaneous drainage group, whereas in the splenectomy group, the number of associated diseases was higher and the length of hospital stay was longer $(p=0.017$ and $p=0.011$, respectively).

Conclusion: Percutaneous drainage and, when necessary, splenectomy should be performed in patients who develop abscess as a result of splenic infarct, whose general health conditions deteriorates and whose symptoms do not improve and who have high WBC count despite medical treatment.

Keywords: Splenic infarct, abdominal pain, splenectomy, splenic abscess
Öz

Amaç: Splenik enfarkt nadir bir dalak patolojisidir ve genel olarak tıbbi yöntemlerle başarılı bir şekilde tedavi edilmektedir. Bu çalışmada ise splenik enfarkta bağlı apse gelişen hastalarda invaziv tedavi seçeneklerinin değerlendirilmesi amaçlanmaktadır.

Yöntemler: Splenik enfarktüs sonucu apse nedeniyle perkütan drenaj veya cerrahi işlem uygulanan 13 hastanın dosyaları retrospektif olarak incelendi. Yaşlar, semptomlar, fizik muayene, radyolojik muayene ve tedavi yöntemleri analiz edildi.

Bulgular: Hastaların yedisi (\%54) kadın, altısı (\%46) erkekti ve

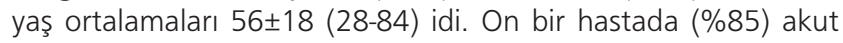
karın, dokuz hastada (\%70) yüksek lökosit sayısı (WBC) (>15000/ $\mathrm{mL}$ ) görüldü. Beş hastada (\%39) perkütan drenaj, sekiz hastada (\%62) ise splenektomi yapıldı; bunların tümü bilgisayarlı tomografi ile splenik apse tanısı aldı. Perkütan drenaj ile splenektomi yapılan hastalarda yaş, cinsiyet, akut karın durumu, WBC, trombosit sayısı ve mortalite arasında fark bulunmazken, splenektomi grubunda eşlik eden hastalık sayısı daha fazla idi $(p=0,017)$ ve hastanede kalış süresi uzundu $(p=0,011)$.

Sonuç: Splenik infarkt sonucu apse gelişen, genel durum bozukluğu olan, tıbbi tedaviye rağmen semptomları ve WBC'si gerilemeyen hastalarda perkütan drenaj ve gerekirse splenektomi yapılmalıdır.

Anahtar Sözcükler: Splenik enfarkt, karın ağrısı, splenektomi, splenik apse
Address for Correspondence/Yazışma Adresi: Serhat Tokgöz, University of Health Sciences Dışkapı Yıldırım Beyazıt Training and Research Hospital, Clinic of General Surgery, Ankara, Turkey E-mail: serhat.tokgoz@yahoo.com ORCID: orcid.org/0000-0003-2716-6222 Received/Geliş Tarihi: 02 Apr 2019 Accepted/Kabul Tarihi: 05 May 2019
${ }^{\circ}$ Copyright 2019 by The Medical Bulletin of istanbul Haseki Training and Research Hospital The Medical Bulletin of Haseki published by Galenos Yayınevi. ${ }^{\circ}$ Telif Hakkı 2019 istanbul Haseki Eğitim ve Araştırma Hastanesi Haseki Tıp Bülteni, Galenos Yayınevi tarafından yayınlanmıştır. 


\section{Introduction}

Splenic infarct is a rare clinical condition and patients usually present to emergency departments with left upper abdominal pain. The most common etiology is hematologic diseases followed by thromboembolic conditions and, less commonly, vascular diseases, anatomic disorders and collagen tissue diseases $(1,2)$. It can be observed in patients presenting to emergency department with the complaint of abdominal pain and during follow-up of patients with chronic diseases. Infarct occurs when one or more branches of the splenic artery are occluded by an embolus or thrombus. Depending on this involvement, partial or complete infarction in the spleen may occur. Medical treatment is the optimal solution for managing cases that are not complicated. In addition, according to the extent of the involvement, the condition may progress to abscess, necrosis and massive splenic infarct. In such scenarios, procedures such as percutaneous drainage and splenectomy may be required. This study aims to analyze patients diagnosed with splenic infarct, who underwent radiological or surgical intervention due to unsuccessful medical treatment.

\section{Methods}

After receiving approval from the local ethics committee, the files of patients, who were diagnosed with splenic infarct in the general surgery clinic at Dışkapı Yıldırm Beyazıt Training and Research Hospital (decision no: 30/14-2016) between August 2012 and January 2016 and underwent a surgical procedure or radiological percutaneous drainage due to the complexity of their condition, were evaluated retrospectively. Splenic infarct patients, who were followed in the general surgery or internal medicine clinics during this period and successfully treated with medical treatment, were excluded from this study. Data on gender, age, symptoms, physical examination, serum laboratory analyses, associated diseases, length of hospital stay, radiological examination, treatment methods and mortality in patients, who were diagnosed with splenic infarct and underwent radiological percutaneous drainage or surgical procedure, were analyzed. Splenectomy and, if needed, additional medical procedures were performed in patients who were not suitable for percutaneous drainage or whose condition was not improved enough despite percutaneous drainage.

\section{Statistical Analysis}

SPSS 16.0 for Windows was used for statistical analysis. The normal distribution of the numerical variables was analyzed by the Kolmogorov-Smirnov test. Data were presented using descriptive statistics, given as mean \pm standard deviation and percentages. The Mann-Whitney $U$ and chi-square tests were used for comparison of numerical and categorical data. A p value of less than 0.05 was considered statistically significant.

\section{Results}

A total of 13 pateints with the mean age of $56 \pm 18$ (28$84)$ years were included in the study. Seven (54\%) patients were female and six (46\%) were male. Eleven patients (85\%) had acute abdomen with guarding and rebound tenderness findings, whereas physical examination findings were normal in two (15\%) patients. Four patients (31\%) had no associated diseases, three had (24\%) one and six patients (46\%) had two or more associated diseases. Serum white blood cell (WBC) count was normal $(5000-10000 / \mathrm{mL})$ in three patients $(23 \%)$, high (10001$15000 / \mathrm{mL}$ ) in one patient (8\%) and very high (over 15000/ $\mathrm{mL}$ ) in nine patients (70\%). Ultrasonography (USG) was used as the primary radiological diagnostic tool in eight (62\%) patients. USG revealed splenic abcess in five (68\%) patients, splenic infarct in one (13\%), intra-abdominal free liquid in one (13\%), and normal findings in one (13\%) patient. All the 13 patients (100\%) were diagnosed with splenic abscess by computed tomography (CT); additional findings, such as intra-abdominal free fluid, retroperitoneal additional abscess and inflammation of the adjacent organ, were observed in five patients (39\%). Five patients (39\%) underwent successful percutaneous drainage only and eight patients with or without previous percutaneous drainage underwent splenectomy. Splenectomy was performed in two patients in whom percutaneous drainage failed. Nine patients (69.2\%) required intensive care monitoring; the average length of hospital stay was $21 \pm 15$ (5-60) days. Four patients required prolonged intensive care unit length of stay due to various diseases. Three patients (23\%) died during treatment.

There was no difference in age, gender, presence of acute abdomen, WBC and platelet count and mortality between patients, who underwent percutaneous drainage as the treatment option, and splenectomy group whereas in the splenectomy group, the number of associated diseases was higher $(p=0.017)$ and hospital stay was longer ( $p=0.011$ ) (Table 1). There was no difference in age, sex, presence of associated disease and acute abdomen, platelet count and length of hospital stay between patients who survived and those who died, however, patients, whose condition resulted in mortality, had higher WBC count ( $p=0.014$ ) (Table 2).

\section{Discussion}

Splenic infarct is a rare condition. Many factors contribute to the etiology of splenic infarct. These factors include thromboembolic events leading to occlusion of the splenic vascular supply (38\%), 
infiltrative hematologic diseases (29\%), splenic vascular diseases (6\%), anatomic disorders (5\%) and collagen tissue diseases $(1,2)$. Hypercoagulability (malignancy, Antiphospholipid syndrome, etc.) can also cause splenic infarction (3). Increase in oxygen requirements due to increased spleen mass can lead to infarction, as the oxygen carrying-capacity of the blood decreases due to anemia in malignant hematological diseases [such as chronic myelogenous leukemia-(CML)]. It has been reported that the rate of development of splenic infarct varies between $50 \%$ and $72 \%$ in patients with CML and myelofibrosis (4). We should also keep in mind that splenic infarct associated with tuberculosis can be observed in endemic regions (5). Even though the etiology is diverse, the main cause is the formation of thrombosis in the vascular structures of the spleen. The etiology of infarct was different in the patient group, who required additional radiological or surgical procedure due to insufficient medical treatment, included in this study. In addition, multiple associated diseases that could contribute to development of thrombosis, and even could be the cause were frequently observed in this patient group.

Patients with splenic infarct usually complain of left upper quadrant abdominal pain and physical examination demonstrates tenderness in this region $(2,6)$. The onset of pain may differ and it can start more than a week before presentation in half of the patients (6). Depending on the severity of the disease, fever and shivering, nausea and vomiting, pleuritic chest pain and left shoulder pain (Kehr's sign) may be observed. Pseudocyst and abscess formation due to infarcts are often accompanied by fullness in the upper quadrant, palpable mass and pleuritic symptoms. These symptoms were observed in all patients, for whom medical treatment was insufficient, during the first application to hospital and in 11 patients (85\%) -except two patients-during clinical follow-up. In the literature, it has been reported that leukocyte count might be high in half of patients (7). High leukocyte count in all patients, except one (92\%), may be due to the fact that the group consisted of advanced-stage and abscess-complicated patients. In patients who died, the leukocyte count was greater than two times than the upper limit normal, which is a warning sign.

USG may not be reliable in the first 24 hours, although it is a good method for evaluating spleen parenchyma (8). With the use of contrast materials that are compatible with USG, diagnosis is achieved at high rates (9). Contrast-enhanced CT is a highly useful diagnostic tool for spleen infarction and is the preferred radiological diagnostic method in clinical practice $(8,10)$. With contrast

Table 1. Comparison of the invasive treatment methods

\begin{tabular}{|l|l|l|l|}
\hline Factor & $\begin{array}{l}\text { Percutaneous drainage } \\
(\mathbf{n = 5})\end{array}$ & $\begin{array}{l}\text { Splenectomy } \\
(\mathbf{n = 8})\end{array}$ & $\mathbf{p}$ \\
\hline Age (year) & $47(28-51)$ & $66(42-84)$ & 0.045 \\
\hline Sex (F/M) & $2 / 3$ & $5 / 3$ & 0.413 \\
\hline Associated disease $\mathbf{0 / 1 / \geq 2}$ & $3 / 2 / 0$ & $1 / 1 / 6$ & $\mathbf{0 . 0 1 7}$ \\
\hline Acute abdomen & 4 & 7 & 0.641 \\
\hline WBC & $15(6.2-15.6)$ & $19.4(7.4-32.5)$ & 0.65 \\
\hline PLT & $675(132-970)$ & $340(30.9-750)$ & 0.171 \\
\hline Hospital stay & $12(5-12)$ & $25(10-60)$ & $\mathbf{0 . 0 1 1}$ \\
\hline Mortality & 0 & 3 & 0.196 \\
\hline WBC: White blood cell, PLT: Platelet, n: Number of the patients F: Female, M: Male & & \\
\hline
\end{tabular}

Table 2. Comparing mortality with univariated factors

\begin{tabular}{|l|l|l|l|}
\hline Factor & $\begin{array}{l}\text { Surviving patients } \\
(\mathbf{n = 1 0})\end{array}$ & $\begin{array}{l}\text { Died patients } \\
(\mathbf{n = 3})\end{array}$ & $\mathbf{p}$ \\
\hline Age (year) & $49(28-84)$ & $1 / 20-74)$ & 0.161 \\
\hline Sex (F/M) & $4 / 4$ & 0.437 \\
\hline Associated disease $\mathbf{0 / 1 / \geq 2}$ & $4 / 2 / 4$ & $0 / 1 / 2$ & 0.260 \\
\hline Acute abdomen & 8 & 3 & 0.577 \\
\hline WBC/mcL & $15(6.2-19.8)$ & $22(19.6-325)$ & $\mathbf{0 . 0 1 4}$ \\
\hline PLT/mcL & $50(132-970)$ & $334(30.9-347)$ & 0.161 \\
\hline Hospital stay (day) & $14(5-41)$ & $24(10-60)$ & 0.573 \\
\hline WBC: White blood cell, PLT: Platelet, n: Number of the patients, F: Female, M: Male & \\
\hline
\end{tabular}


scintigraphy and angiography, contrast-enhanced magnetic resonance imaging enables diagnosis at very high rates. In accordance with the literature, majority of our patients were diagnosed with USG (81\%) and all patients were diagnosed with $\mathrm{CT}$, and abscess formation was also identified.

Patients diagnosed with splenic infarct should be hospitalized and closely monitored. Patients, who do not present poor general condition or sepsis symptoms, are usually successfully treated with medical treatment that combines hydration, oxygen support and analgesia (7). 20\% of patients with splenic infarct may develop complications such as splenic abscess, hemorrhage, rupture and pseuodocyst formation, which may require drainage or surgery (1). Surgery is indicated in case of persistent symptoms, complication development, sepsis and septic emboli despite treatment in patients with splenic infarct. All patients had radiological abscess formation and three patients had sepsis symptoms and poor general condition. Radiological percutaneous drainage was performed first and, when it was not applicable or sufficient, splenectomy was performed.

Splenic abscess is associated with high mortality (12$47 \%$ ) even though it is a rare condition that can be caused by neoplasia, immunodeficiency, trauma, metastatic infection, hemoglobinopathies, splenic infarct and diabetes mellitus (11). Although percutaneous drainage is an effective and safe technique, surgery is an appropriate method for splenic abscess (12). Percutaneous drainage is performed for uniloculated or biloculated abscesses and high-risk surgical patients while it is appropriate to be performed in patients with multiloculated abscesses or patients who had an unsuccessful surgical drainage during surgical intervention (11). Conservative methods, such as partial splenectomy, are suggested due to increased susceptibility to infections and thromboembolic events (12). Splenectomy may be averted by performing percutaneous drainage in early stage (13). Percutaneous drainage and, when indicated, splenectomy were performed in patients, who developed abscess. Eight patients underwent splenectomy; two of them had abscess formation covering the entire spleen and additionally in adjacent regions. Four of them had multilocular abscesses and two underwent failed percutaneous drainage. It may be appropriate to evaluate each patient individually (14).

\section{Conclusion}

Splenic infarct should be kept in mind for differential diagnosis in patients with associated diseases as it can be a rare cause of left upper quadrant pain. Symptomatic treatment should be opted for patients, who do not present any complication. Percutaneous drainage and, if necessary, splenectomy should be performed in patients, whose symptoms do not improve, who have high WBC count, high fever and worsening general condition or develop complications evident in radiology despite medical treatment. In such cases, it is vital to take a timely decision for surgery due to associated diseases and high mortality.

\section{Authorship Contributions}

Writing: H.K., K.B.Y., M.A., Concept: H.K. Design: H.K., Ş.B. Data Collection or Processing: S.T., S.T., H.A.D., O.E. Analysis or Interpretation: H.K., M.A., Literature Search: C.A., M.A., S.T.

Conflict of Interest: The authors reported no conflicts of interest. The authors alone are responsible for the content and writing of this article.

Financial Disclosure: The authors reported that this study received no financial support.

\section{References}

1. Jaroch TM, A. Broughan T, Hermannn ER. The natural history of splenic infarction. Surgery 1986;100:743-50.

2. Antopolsky M, Hiller N, Salameh S, et al. Splenic infarction: 10 years of experience. Am J Emerg Med 2009;27:262-5.

3. Görg C, Seifart U, Görg K. Acute, complete splenic infarction in cancer patient is associated with a fatal outcome. Abdom Imaging 2004;29:224-7.

4. Nores M, Phillips EH, Morgenstern $L$, et al. The clinical spectrum of splenic infarction. Am Surg 1998;64:182-8.

5. Baskent A, Ozakay B, Eren A. Akut Karında Nadir Bir Neden: Splenik Infarkt Olgu Sunumu. İstanbul Med J 2001;4:26-8.

6. Lawrence YR, Pokroy R, Berlowitz D, et al. Splenic infarction: an update on William Osler's observations. Isr Med Assoc J 2010;12:362-5.

7. Ozakin E, Cetinkaya O, Baloglu Kaya F, Acar N, Cevik AA. A Rare Cause of Acute Abdominal Pain: Splenic Infarct (Case Series) Turk J Emerg Med 2015;15:96-9.

8. Robertson F, Leander P, Ekberg O. Radiology of the spleen. European. Radiol 2001;11:80-95.

9. Chen MJ, Huang MJ, Chang WH, et al. Ultrasonography of splenic abnormalities. World J Gastroenterol 2005;11:4061-6.

10. Schattner A, Adi M, Kitroser E, Klepfish A. Acute Splenic Infarction at an Academic General Hospital Over 10 Years: Presentation, Etiology, and Outcome. Medicine 2015;94:1363.

11. Nagem RG, Petroianu A. Subtotal splenectomy for splenic abscess. Can J Surg 2009;52:91-2.

12. Chang KC, Chuah SK, Changchien CS, et al. Clinical characteristics and prognostic factors of splenic abscess: a review of 67 cases in a single medical center of Taiwan. World J Gastroenterol 2006;12:460-4.

13. Shetty M, Deme $S$, Mohan $K$, et al. Experience with Splenic Abscess from Southern India. J Clin Diagn Res 2016;10:OC22-OC5.

14. Lee WS, Choi ST, Kim KK. Splenic abscess: a single institution study and review of the literature. Yonsei Med J 2011;52:288-92. 